\title{
Indigenous Languages and the Development Question in Africa
}

\author{
Adeyemi J. Ademowo, PhD \\ Cultural Studies Unit, \\ General Studies Department,Afe Babalola University, \\ Ado-Ekiti.
}

\begin{abstract}
Africans have been yearning for change and development for years; but Africa is still among the underdeveloped continents in the world. In this work, the author examines the development question in Africa, with particular focus on how indigenous languages can be used as a catalyst. Our position here is that the continued neglect of the indigenous languages as medium of everyday communication, in education, and its derision by the African elites in favour of the foreign languages, have deprived Africans of enjoying the benefits and contributions that indigenous languages can make to development. The author posits that African governments and Africans must reconsider their attitude to indigenous languages if indeed they desire the much 'sought after' development.
\end{abstract}

Keywords: Africa, African Development, Indigenous languages, underdevelopment.

\section{INTRODUCTION}

For Africa to maintain its identity and attain meaningful development, African nations must use their languages to empower their people who will then be able to contribute to their full potential. Mohochi (2003:86)

Nature has conditioned mankind to varieties and diversities that makes each human and human group fashion different ways of dealing with the challenges associated with the peculiar diversities they are confronted with. Hence, one can define culture as nature's own way of organising people all over the world; each with its own peculiar environment, skills, challenges and knowledge.

Etymologically, however, the word "culture" has its root in the Latin word colere which means "to cultivate". This connotes the idea of cultivating one's self in an effort to attain the wisdom which was found in Greek thought: the idea through which human beings become developed and actualises their full potentials within the ambit of their quest for survival (Ademowo 2011:7; Ukpokolo 2004:24). The significance of culture to human survival was further underscored by Kroeber and Kluckholm who compiled 164 definitions of culture to include (Ukpokolo 2004:25):

1. the total way of life of a people;

2. the social legacy the individual acquires from his group;

3. way of thinking, feeling and believing;

4. an abstraction from behaviour;

5. a set of standardized orientations to recurrent problems;

6. a set of techniques for adjusting both to external environment and other men; among others.

What is glaring from the above definitions is that culture is core and instrumental to man in his/her daily quest to conquer and annex his/her physical and social world for diverse purposes, and in development. Thus, UNESCO (2002) posited that:

Culture should be regarded as the set of distinctive spiritual, material, intellectual and emotional features of a society or social group, and that it encompasses in addition to art and literature, lifestyles, ways of living together, values systems, traditions and belief (UNESCO, 2002). 
There are two aspects which are vital to culture, namely, material and non-material. As important as the material aspects of culture are, the non-material aspects of culture are considered among scholars to be more vital to group identity (Oladipo, 2005). Non-material aspects of culture are the contingent aspects of culture that must be preserved for the sake of future generations. However, if the nonmaterial aspects of culture must be preserved and communicated meaningfully to the benefit of future generations, it needs the help of language, because language is the vehicle for communicating and transmitting the non-material aspects of culture.

Language, however, is not a neutral medium for the formation of meanings and knowledge about an independent object world 'existing' outside of language. Rather, language is constitutive of those very meanings and knowledge; it gives meanings to material objects and social practices that are brought into view and made intelligible. Language, therefore, becomes an aspect of culture that must exist so as to preserve and communicate culture from generations to generations.

Hence, language can be rightly described as the carrier of culture: when language dies, the culture dies invariably. Language is also central to the sustenance of a group of people for it is the vehicle through which other constituents of cultures are communicated. In fact, it is the primary vehicle through which human culture is acquired, shared and transmitted (Hammond, 1975). Without language, there is bound to be problem in the society for thoughts, ideas, information, etc would be incommunicado. Little wonder then that Schaefer (2000) sees language as the foundation of every culture that dictates how such humans in such societies organise and manage their affairs through communication of diverse forms. One can then agree with Bewaji (2002) that language is 'central to the interactive processes and meaningful construction of realities in human societies'.

Lugraham (1975) identified four ways by which language is used in the society, namely: as a means of expression; for the purposes of record; to set matter in motion; and as an instrument of thinking. Based on these functions that it performs, some scholars are of the view that language, as a means of communication, is as vital to human socialization and existence, just as blood is vital to the human body. In fact we will not be wrong if we describe culture as inconceivable outside of language. This explains why languages are "sometimes regarded as a reservoir of culture which controls human thought and behaviour and sets the boundaries of the worldview of its users" (Alamin 2002). Languages are also described as important aspect of human growth and sociability of a people hence it is among the very first forms of behaviour that we learn as children, and later when we learn 'other skills and acquire more knowledge, much of this reaches us only through the medium of language' (Burling, 1970).

Culture and language, from our discussions thus far, are therefore so intertwined in such a way that the death of a language is a bad omen for elements of culture that such language carries. If this is so, it is only appropriate that scholars of culture caution any human society that treats its language with disdain to refrain from such for the sake of the elements that it carries, and for the sake of other benefits such cultures can produce.

\section{African Languages and Africans' Prejudice}

Current attitudes towards, and perceptions of, indigenous languages in Africa are, to a large extent, attributable to a show of class among the elite as well as the colonial language policies which independent African states have been unable to change considerably. With the benefit of hindsight, one can opine that the African elites and the neo-colonial administrations in many African states have neglect and not make optimum use of the indigenous African languages even when they are aware of the important role of such languages in shaping ones identity. Rather African leaders have initiated language policies that pushed the indigenous languages to the backseat and promoted the use of Western/European language as language of government and that of the elites (Ishola, 2010; Mohochi, 2005).

In general, the new African elites and postcolonial educational policies were, ignorantly or deliberately, aimed (currently) at making Africans view their languages as inferior and less competent while holding the colonial languages in high esteem. This position has been vigorously challenged (Afolayan 1976); yet the new African ruling elites, today, retained their privilege position by continuing in the tradition of the colonial masters. Indeed, knowledge of the colonial languages 
became an important weapon in the search for employment, class and privileges. It has since been seen "as a mark of education and a major contributor to one's socio-economic advancement" (Ishola 2010). According to Mbaabu (1996), "opportunities for good jobs and higher education depended on one's knowledge of the foreign language" rather than one's intellect and skills. To date, many are those who still feel that knowledge of English, French and other colonial languages opens doors for the future. Bamgbose (1983) opines that within the education system most students see very little value in learning African languages. Similar views were expressed by high school students learning Kiswahili in Kenya in a research by Mohochi (2005). Most participants in Mohochi (2005) study, for instance, held that they see "very little to be gained in future, especially in the job market, by studying Kiswahili”.

The truth of the matter is that many of the so-called African states' national and/or official languages are legacies of the colonial masters. Consequently, Africa is divided linguistically as English, French, and Portuguese speaking; classifications that make very little sense especially when you consider the percentages of people who can actually function in those languages. The situation may well be worse in countries such as Nigeria, Ghana, Uganda, among others. Given those conditions, it is foolhardy to continue with policies that give English precedence, unless of course the purpose is to exclude the masses (Bamgbose 1983, Mohochi 2005; Ademowo 2012). It is therefore important that African indigenous languages should be studied and put to everyday use with the intension to show their logical structure and that everyone is welcome onboard to contribute meaningfully and participate in governance (Oladipo 1996).

Wilhelm (1963: 198 in Adegbija, 1994) opines that language and culture function as catalysts for development in the following distinct ways:

1. As a means of creating order

2. As an instrument of the achievement of social integration

3. To make events in human experience intelligible and significant and as regulator of change.

Would it then be wrong (bearing in mind the current state of indigenous languages) to pronounce that it is Africa's inability to come to terms with these intricate cultural and historical benefits of indigenous languages that has contributed immensely to rendering her developmental quest a fruitless or nearly futile exercise? Can one then suggest the need to rejuvenate the use of indigenous languages so as to enhance her development? Of course, the foregoing questions would not be out of place, as answers to both questions might fade the argument of those who argued against African moral and rational capacity, and underscore the fact that Africa has a value system that is capable of making its world humane, worth living and developed.

\section{The QUeST FOR DEVELOPMENT IN AFRICA}

Development, despite years of discourse on the subject, remains largely a buzzword, because its meaning is still elusive, vague and depends on how it is used. However, over the years, it has been tied to any issue 'focused on how to create a better standard of living and makes living fulfilling' (Rist, 2007). And whenever a condition becomes undesirable with the possibility of a better option, then 'development' becomes the ready toast of all. Hence, the present condition of Africa in the comity of continents, when there is the possibility of 'better Africa', has been a source of worry and subject of talks for decades now. Indeed, the state of development in Africa today is such that there is hardly any African (and even non-Africans) who does not crave for a better Africa.

However, Africa states, and Africans, have been found wanting in the area of 'matching desire with action'; they have organized and participated in talk-shops (summits, conferences, workshops, etc) where "blue and white prints on development have been discussed, yet there has been no, or very little, result to show in terms of economic, social, cultural and techno-scientific development" (Ademowo, 2012). Today, like decades ago, many African leaders are still dying in Western hospitals while their national hospitals remain unequipped. Today, although Africa is rich in natural resources, they still pay heavily to import the products of crude oil they produce from other continents. One can go on and on, with the list of this "desire not matched with action' situations but then, solution rather than belabouring the obvious is far more desired.

The approach we favour in African negotiation for development is that of "no country is an island approach'. Developmental ideas can and should be shared and then innovation can, and should, be 
supported for the sake of new breakthroughs which will be invaluable for better living. But then, innovation cannot take place in a void, three issues are involved, as Ademowo (2011:28) suggests:

1. Application of human knowledge acquired in form of skills, pure theoretical knowledge and techniques

2. Maneuvering of human activities (the uncommon way of doing things)

3. Finding solution to problems, and creating situations that will make life and living better.

The above outlined issues necessarily follow one from the other. Hence, since there is an existing wide developmental gap, between the west and Africa, Africans need to understand the ingredients needed for development. To have a grasp of 'what is' means they need to understand the present theories and patterns of inventions. And there lies the crux of the lacuna identified (in this work): Africans are not getting the theories right because they do not understand the theories. The 'so-called language of science and 'imported' governance theories in many African countries is colonial, foreign languages, namely, English, French, Portuguese, etc. The indigenous languages are not priortised in transmission of ideas despite its proven ability in enhancing cognitive understanding in learning. Japan is a good example of a country that has realised this indubitable fact. It developed its indigenous language to accommodate techno-scientific terms and this has resulted in techno-scientific breakthroughs even in the rural areas. In less than five decades, Japan which used to be among the third world/underdeveloped countries is now one of the most developed countries in terms of what their knowledge of science and technology offers them. The question is: what can African leaders learn from this when the language policy remains foreign to the people?

The language policy in African countries, close to five decades after the last African state breath fresh air of freedom (also known as 'independence') has fervently remained perpetually un-African. Bamgbose (1983) identified six types of barriers militating against effective education, using the West African languages as good examples, which is also true for other African languages:

1. Socio-historical barriers which are related with multiplicity of languages and the inherited colonial policies.

2. Linguistic and pedagogic barriers that cover necessary language planning activities as well as training and supply of teachers.

3. Economic barriers that relate to the "prohibitive cost" of the mother tongue language enterprise, a point which has already been taken up above.

4. Theoretical barriers arising from conflicting claims about the superiority of mother tongue language or foreign language policies in bilingual education.

5. Attitudinal barriers which could be either political or psychological/social.

6. Political attitudinal barrier relates to the basic attitude of the state to language education, including the pretense to be proclaiming a policy in favor of mother tongue languages while doing nothing to implement the policy (Bamgbose 1983: 23).

7. What is significant to note here is that indigenous languages are utterly marginalised in most African states and they are not properly deployed or recognised as development catalyst.

\section{DEPLOYING InDIGENOUS LANguages For African Development}

There is an urgent need to match words with actions in our agenda for development. Hence, aside protecting and promoting indigenous languages, attention must be paid to these four important spheres of life which would make our development holistic and sustainable:

\section{INDIGENOUS LANGUAGES AS LANGUAGE OF GOVERNANCE}

Sizeable percentage of the African population are still "illiterates" who can converse meaningfully only in indigenous languages. It is sad to note that many African governments conduct their business in languages that vast majority of its people can hardly understand. The masses therefore find it difficult to comprehend issues, policies and general socio-political and economic affair of government as it affects them. Significant is that this scenario alienates the vast majority from been able to make sense of issues bordering the state, and barred technically from contributing. The privileged 
few/arrogant educated elites in the helm of governance speak in "strange" languages that confuse the masses and render them perpetually oppressed. Thus, parliamentary and judicial processes, except at the Customary Courts level, are largely discussed in non-indigenous languages. It is a common practice in Nigeria, for example, to see government officials read long speeches in English on important national issues or national days to a mammoth crowd in complete disregard of the fact that most, though cheering widely, have no idea of what it is all about.

A good instance of this is was a scenario at the House of Representative when an honourable member of the Nigerian House of Representative (the lower federal parliament) thanked his colleagues noting that "he appreciates Hon. Patrick Obiahagbon (his colleagues) for his contributions to an ongoing deliberation for he has said a lot, even though he does not understand what Hon. Patrick has said in 'big English'(Queen English)". This is indicative of the sense that the masses make from jamboree speeches of government officials. More so, there are commonplace instances of the elites trying to outdo one another in speeches (spoken English) at the detriment of the masses. Some elites are however clever enough to deploy indigenous languages during electioneering campaigns or other mobilization agenda. This cunning class of elites often use or address the masses in indigenous languages such as Hausa, Igbo or Yoruba, singing and dancing while touching on "juicy" political promises. The term 'cunning' is used to describe this class of elite because once elected they return to their indigenous languages denigration, addressing the people hitherto addressed in indigenous languages, in Queen English that they could hardly comprehend. One way to addressed this unwanted trend is to adopt language policies that are people-centered; with this policy, indigenous languages will not only be found useful during the electioneering processes but also after elections.

More worrisome is the fact that in many African countries, Nigeria for instance, the national constitutions are only available in the official languages. The laws are only available in foreign European languages of the colonial masters. In Nigeria, for instance,the most recent attempt to translate Nigerian constitution into an indigenous language (Yoruba Language, to be precise) was undertaken by a young Nigerian, named Bode Oje (in 2013). The same lots befell many relevant policy documents that should be at the finger tips of all Nigerian, so that people could be aware and participate actively in governance. The obvious negative effects of this is that the genius of the vast majority is left untapped, and this is inimical to development.

\section{INDIGENOUS LANGUAGE AND VALUES}

Values are veritable ingredients for development anywhere. It is therefore an axiomatic truth that when right values such as honesty, hard-work, patience, etc which are part and parcel of indigenous folktales, proverbs, music, myths and legend are imbibed by all and sundry in the society, people would cultivate a right frame of mind required for development (Ishola, 2010; Ademowo \& Balogun, 2014). The import of this is that when people are morally or culturally developed, it would automatically reflect in their social and physical construction of values and attitude to self, communal goals and projects.

Noteworthy is that the present system of socialisation are communicated in foreign languages, laden with foreign trait; it is also the means through which other values are transferred with inimical implications on the African culture and values.

\section{INDIGENOUS LANGUAGES AND EDUCATION}

The role of education in development cannot be over-emphasized. Education develops people's mindframe and enable ths develops people's skills and intellectual abilities necessary for development. Sadly, the language of education in many African states have been largely European, despite the overwhelming evidences that indigenous languages as medium of education would enhance best result in learning. Little wonder that despite being certificated, many African graduates find it difficult to put their education to the service of transforming our environment through the provision of amenities capable of making life easier. Thus, education has not been exploited as a weapon for transformation linens.

\section{INDIGENOUS LANGUAGESKAND CULTURAL IDENTITY}

Indigenous languages are carriers of cultural identity. Noting the inextricable link between culture and development, culture being a catalyst for development as expressed in intangible cultural elements to such as oral tradition, customs, rituals and various skills which constitute what gives identity to people. This cultural heritage in stories, folktales, proverbs, idioms, taboos and poetry teaches valuable ideas such as dignity, hope, sense of duty, hard work, faithfulness, accountability, 
transparency, honour and other humane qualities. Significantly, culture in this sense, recognises biodiversity as natural ways of organizing people all over the world, each with its own peculiar skills and knowledge sufficient to cope with challenges. Indigenous languages, however, remain the hallmarks of a people's identity and cultivation of mind frame needed in boosting the self-confidence, motivation and innovation that drive development. Language is part of culture as well as a vehicle for the expression of culture, and culture is the hallmark of every meaningful development (Ademowo and Balogun 2014).

As an essential part of culture and an identity, language is more than a means of communication. According to Walnork (1969) language is used:

1. For phatic communion i.e as a social regulator

2. As an instrument of action

3. To convey order and information

4. To influence people

5. To enable self-expression, and

6. To embody and enable thought.

Taking Walnork seriously, it becomes obvious that no human society can exist to experience development without effective, explorative use of and development of its language. In looking at the utilitarian value and explorative use of language, Ogunsiji (2001) opined that no other language can effectively displace one's mother tongue, and that there is obvious danger in over-blowing the importance of lingua franca at the expense of the indigenous languages. Aside the efforts of linguistic school of thought, contemporary African philosophers are of the opinion that philosophy can only live up to its pragmatic role in social reconstruction in Africa if she takes cognizance of the importance of indigenous language. This is in line with the opinion of Wiredu (1995) who argued for a development catalyst called conceptual decolonization, that prioritized African indigenous languages to take the lead role in the search for development. It is also in line with this tradition that Ngugi Wa Thiong'o resolved to do scholarship solely in African language before being translated into other languages.

\section{Conclusion}

Our position in this paper is that indigenous languages can play vital role in African quest for development. Indeed, we are convinced that there is an urgent need to deliberately inculcate and imbibe right social values as sine qua non for people-centered development; and that people must endeavour to make culture work for the purpose of development; if Africa must develop.

As it were, it is glaring that those in government in many African countries, are not doing enough to promote the use of indigenous languages. Granted that Africa has so many languages, and enormous resources would be required to develop all of them to deal with contemporary realities, but we do not need to develop all the languages at once. We recommend that Africans government must match actions with words by adopting policies that would promote their use by all and sundry, including the masses and the 'exploitative' elites. A good starting point would be to develop and adopt those African languages that are cross-ethnic and have a wider speakers-base in particular regions; and also to retain the foreign languages in minor roles.

\section{REFERENCES}

Ademowo, A. J. (2011). Culture, Technology and Human Development. Saarbrucken, Germany: LAP Lambert.

(2012) 'Indigenous Languages and Techno-Scientific Development in Africa'. Volume 23(2). Lumina. ISSN: 2094- 1188 p.1-18

Ademowo, A.J \& Balogun N.O. (2014). Proverbs, Values and the Development Question in Contemporary Africa: A Case Study of Yoruba Proverbs. Anthropologia. Vol. 14(2).

Afolayan, A (1976), 'The Six-Year Primary Project in Nigeria' in Ayo Bamgbose (ed.) Mother Tongue Education: The West African Experience London, Paris: The UNESCO Press 
Alamin, M.(1993). Language and the Quest for Liberation in Africa: The Legacy of Frantz Fanon' Third World Quarterly, Vol.14, No. 2.pp. 351363. htt: //links. jstor. org /sici? sici $=01436597 \%$ 281993\%2914\%3A2\%3C351\%3ALATQFL\%3E2.0.CO\%3B2-G.

Alamin, M. \& Mazrui, A. (2002). Black Reparations in the Era of Globalization. Binghamton: The Institute of Global Cultural Studies.

Bamgbose, A. (1983). Education in Indigenous Languages: The West African Model of Language Education. The Journal of Negro Education, Vol. 52, No. 1 (Winter, 1983), pp. 57-64.

Bewaji, J.A.I. (2002). African Languages and Critical Discourse. Oladipo, O. (ed.) The Third Way in African Philosophy: Essays in Honour of Kwasi Wiredu. Ibadan: Hope Publications.

Burling, R. (1970). Man's Many Voices. New York: Holt, Rinehant \& Winston.

Hammond, P. (1975). Cultural and Social Anthropology. New York: Macmillan Press.

Ishola, A. (2010). Limits of Tolerance: the Future of African Cultures. Making Culture Memorable: Essays on Language, Culture and Development. Ibadan: Hope Publications.

Mbaabu, I. (1996). Language Policy in East Africa, Educational Research and Publications: Nairobi. Mberia, K. 2000. "Kiswahili and Other Indigenous Languages in Performing Arts", paper presented at the National Drama Training workshop 2000, on Performing Arts for National Development, Kenyatta University, 21-25 Aug. 2000.

Mohochi, E.S. (2003) "Language choice for development: the case for Swahili in Kenya", Journal of African Cultural Studies. Vol. 16 no. 1, pp. 85-94.

2004). Turning to Indigenous Languages for Increased Citizen Participation in the African Development Process <http://www.codesria.org/Links/conferences/general_assembly11/papers/mohochi.pdf >.

2005) "Language and Regional Integration: Foreign or African Languages for the African Union?" In F.A. Yieke (ed.), East Africa: In search of national and regional renewal, Codesria, Dakar, pp. 41-54.

National Policy on Education. (2001). Rep. Ed. Lagos: National Educational Research Council.

Ogunsiji, A. (2001). Utilitarian Dimension of Language in Nigeria, In: Herbert Igboanusi (ed.) Language Attitude and Language Conflict in West Africa. Enicrownfit Publishers.

Oladipo, O. (1992). The Idea of African Philosophy. Ibadan: Hope Publications.

(1996), Philosophy and the African Experience (Ibadan: Hope Publications

(2009). Philosophy and Social Reconstruction in Africa. Ibadan: Hope Publications.

Osakwe, S.O. (2013). Context of Usage and Aesthetics of Selected Proverbs form Southern Nigeria. Journal of Language, Technology and Entrepreneurship in Africa. 4(1): 16-30.

Phillipson, R. \& Skutnabb-Kangas, T. (1995). "Language rights in postcolonial Africa", In. SkutnabbKangas, R. Phillipson \& M. Rannut (eds.), Linguistic Human Rights:

Overcoming Linguistic Discrimination. Mouton de Gruyter: Berlin \& New York, pp. 335-345.

Rist, G. (2007). Development as a Buzzword. Writework.com. retrieved 01:16, April 14, 2012, www.writework.com/essay/development-buzzword-gilbert-rist.

Salawu, A. (2006). Indigenous Language Media in Africa. Lagos: CBAAC.

Schaefer, R (2000). Sociology: A Brief Introduction ( $3^{\text {rd }}$. Edit), San Francisco: McGraw Hill.

Soyinka, W. (1998). Development and Culture: Twice Bitten, the Fate of Africa's Cultural Producers. Discussion of the African Leadership Forum. African Leadership Forum. Ota, Nigeria.

Ukpokolo, I. (2004). Philosophy Interrogates Culture: a Discourse in Philosophical Anthropology. Ibadan: Hope Publications.

UNESCO, (2002). Draft of an International Convention for the Safeguarding of Intangible Cultural Heritage.

Wallnock, J. (1969). Language and Linguistics. London: Heinemann.Wilhelm, A. (1963). 'Language and Culture' in Adegbija, E. (1994), 'The Context of Language Planning in Africa' in Putz, M (ed.) Language Contact, Language Conflict Amsterdam/Philadephia: John Benjamins.

Wiredu, Kwazi. (1995). Conceptual Decolonization in African Philosophy: 